EISSN:2706-7920 ISSN: 2077-4435

DOI: $10.36632 / \mathrm{csi} / 2021.10 .1 .6$

Journal homepage: www.curresweb.com

Pages: 58-71

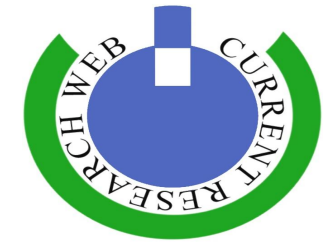

\title{
Genetic Diversity of Egyptian Barley Using Agro-Physiological Traits, Grain Quality and Molecular Markers
}

\section{Samah A. Mariey ${ }^{1}$, Eman N. Mohamed ${ }^{2}$, Zeinab E. Ghareeb ${ }^{3}$ and Engy S.M.R. Abo Zaher $^{4}$}

${ }^{1}$ Barley Res., Dept., Field Crops Res. Inst., ARC, Giza Egypt.

${ }^{2}$ Seed Technology Res., Dept. Field Crops Res. Inst., ARC, Giza, Egypt.

${ }^{3}$ Central Lab. for Design and Stat. Anal. Res., ARC, Giza, Egypt.

${ }^{4}$ Crop physiology Res., Dept. Field Crops Res. Inst., ARC, Giza Egypt.

Received: 20 December 2020 Accepted: 15 January $2021 \quad$ Published: 30 January 2021

\begin{abstract}
Assessment of phenotypic and genotypic diversity is one of the principal and important steps in plant breeding programs. In this study, field screening analysis was carried out in Sakha Agricultural research station during two growing seasons 2018/ 2019 and 2019/ 2020 to investigate the phenotypic diversity among 15 Egyptian barley cultivars using physiological, grain quality, grain yield and yieldassociated traits and to assess the genetic diversity by using Sequence-Related Amplified Polymorphism (SRAP) marker analysis. Analysis of variance of the traits showed high variability among all cultivars under study with respect to all agronomic and grain quality characteristic studied traits. Cluster analysis classified the cultivars in four groups and showed that genetic variation based on the all studied traits among the barley cultivars. Ten SRAP combination primers was used, the average percentage of polymorphic loci of the $67.9 \%$ and the average band number amplified from each pair of primers was $6.5 \%$ bands, of which included $9.0 \%$ polymorphic bands. Highest (PIC), was related to primer me6+em5 was $(0.94)$ indicating that this primer is highly informative. The dendrogram of SRAP markers had clustered all the Egyptian cultivars into four groups each group include the most closed cultivars. The results of the present study showed that there were high genetic information differences among Egyptian barley cultivars which offered new information about the genetics relationships between Egyptian barley cultivars which they are useful for cultivar identification and for their utilization in further barley programs for environments stress.
\end{abstract}

Keywords: Hordeum vulgar, agronomical traits, physiological traits, grain quality analysis and SRAP markers.

\section{Introduction}

Barley (Hordeum vulgare L.) is considered as a one of the most economical and important cereal crop which is ranked fourth crop after rice, wheat and maize in the world's food crop productions according to food and agriculture organization (FAO, 2017). Also, it is considered a major source of food for animal and people, with an extra tolerant to unfavorable environmental conditions than any other cereals which were less adapted (Abu El-lail et al., 2014).

Assessments of genetic diversity and genetic improvement have always been important goal for crop breeders, which depends on available dissimilarity in the germplasm and could be explored through a specific or a combination of different breeding methods. (Sharma et al., 2017). Physiological, morphological, biochemical, grain quality markers and statistical analysis methods were used to study the genetic diversity in barley breeding programs ( Hammami et al., 2016, Mariey et al., 2017a, Naser et al., 2018, Mariey et al., 2018c and Hammami et al., 2020). However these methods are limited for some stages of plant growth and might be affected by environment. 
Molecular markers (a potential resource for genetic diversity studies) allow the identification and characterization of plant genotypes through direct access to the hereditary material. In crop species, molecular markers are applied in different aspects and are useful in breeding programs. Also, molecular marker could function as a harmonizing tool for documenting species (Ismail et al., 2016). In barley, different DNA markers were used i.e., RAPD (Guasmi et al., 2012), ISSR (Monireh et al., 2014) SSR (Varshney et al., 2008), SNP (Sallam et al., 2018) and SCOT (Dora et al., 2017). Sequence-Related Amplified Polymorphism (SRAP) as a new DNA marker has been established to be a suitable tool for genetic diversity studies more than other markers because of its simplicity, reproducibility, discloses numerous and co-dominant markers (Li and Quiros, 2001). SRAP marker is used for classification and genetic diversity studies many cereal crops including barley (Yang et al., 2010, and Mariey et al., 2017b and 2018b). This study aimed to evaluate genetic diversity among 15 Egyptian barely cultivars for agro-physiological traits and grain quality using SRAP marker, in order to classificate them and use in barley breeding programmers for environmental stresses.

\section{Materials and Methods}

\subsection{Phenotypic DiversityEvaluation}

\subsubsection{Plant material and Field experimental design}

Fifteen Egyptian barley cultivars (Hordeum vulgar L.) were used in this study. The grain type, row type and pedigree are shown in (Table1). Theses cultivars were grown at Sakha Res., Station during two growing seasons 2018/2109 and 2019/2020. There were planted in a Randomized Complete Block Design (RCBD) with three replicates, each plot was devoted to one cultivar which was planted in six rows of $3.5 \mathrm{~m}$ long, spread out with $20 \mathrm{~cm}$ among rows (plot area $=4.2 \mathrm{~m}^{2}$ ).

Table 1: Name, grain type, row type and pedigree of the15 Egyptians barley cultivars.

\begin{tabular}{|c|c|c|c|c|}
\hline No. & $\begin{array}{l}\text { Cultivars } \\
\text { names }\end{array}$ & $\begin{array}{l}\text { Grain } \\
\text { type }\end{array}$ & $\begin{array}{l}\text { Row } \\
\text { type }\end{array}$ & Pedigree \\
\hline 1 & Giza 123 & Hulled & Six & Giza 117/FAO 86 \\
\hline 2 & Giza 124 & Hulled & Six & Giza 117/Bahteem 52// Giza 118/FAO 86 \\
\hline 3 & Giza 125 & Hulled & Six & Giza117 / Bahteem52// Giza118 /FAO86(sister line to G.124 \\
\hline 4 & Giza 126 & Hulled & Six & BaladiBahteem/S D729-Por12762-BC. \\
\hline 5 & Giza 127 & Hulled & Two & W12291/B0gs//Hamal-02 \\
\hline 6 & Giza 128 & Hulled & Two & W12291/4/11012-2170-22425/3/"Apam"/"B65"//"A16" \\
\hline 7 & Giza 129 & Hulless & six & DeirAlla 106/Cel//As46/Aths*2" \\
\hline 8 & Giza 130 & Hulless & $\operatorname{six}$ & Comp.cross"229//Bco.Mr./DZ02391/3/DeirAlla 106 \\
\hline 9 & Giza 131 & Hulless & six & $\begin{array}{l}\text { CM67B/CENTENO//CAMB/3/ROW906.73/4/GLORIABAR/ } \\
\text { COME-B/5/FALCON BAR/6/LINO }\end{array}$ \\
\hline 10 & Giza 132 & Hulled & Six & Rihane-05//AS 46/Aths*2Athe/ Lignee 686 \\
\hline 11 & Giza 133 & Hulled & Six & ICB91-0343-0AP-0AP-0AP-281AP-0AP \\
\hline 12 & Giza 134 & Hulled & Six & ICB91-0343-0AP-0AP-0AP-289AP-0AP \\
\hline 13 & Giza 135 & Hulless & six & $\begin{array}{l}\text { ZARZA/BERMEJO/4/DS4931//GLORIABAR/COPAL/3/SEN/5 } \\
\text { /AYAROS }\end{array}$ \\
\hline 14 & Giza 136 & Hulless & six & $\begin{array}{l}\text { PLAISANT/7/CLN-B/LIGEE640/3/S.P-B//GLORIAAR/ COME } \\
\text { B/5/FALCONBAR/6/LINOCLN-B/A/S.P- } \\
\text { /LIGNEE640/3/S.P-B//GLORIA-BAR/COME } \\
\text { B/5/FALCONBAR/6/LINO }\end{array}$ \\
\hline 15 & Giza2000 & Hulled & Six & Giza117/Bahteem52// Giza118/ FAO86 / 3/Baladi16/ Gem \\
\hline
\end{tabular}

\subsubsection{Phenotypic Studied Characters}

After 70 days from sowing, physiological traits were recorded, i.e., flag leaf area $\left(\mathrm{cm}^{2}\right)$ which measured by multiplying the leaf length width with multiplying factor 0.75 , and total chlorophyll content (SPAD) which was measured using chlorophyll meter (SPAD-502 Minolta Camera Co. ltd., Japan). At harvest time, grain yield (GY) was determined from the yield of the central area $\left(4.2 \mathrm{~m}^{2}\right)$ of the plot, and then transformed to the unit of $\left(\operatorname{ard~fed}^{-1}\right)$. Grain yield related traits were measured such as number of grains spike ${ }^{-1}(\mathrm{NG} / \mathrm{S})$, number of tillers $\mathrm{m}^{2}\left(\mathrm{NT} / \mathrm{m}^{2}\right)$ and thousand kernel weight $(\mathrm{TKW} /$ g). 
The harvested grains of the 15 Egyptian cultivars were grounds to a fine powder to pass through $2 \mathrm{~mm}$ mesh to measure the grain quality characters such as total starch content (TSC) which was determined by phenol sulfuric method (Dubois et al., 1956), grain protein content (GPC) by using Micro-Kjeldahl digestion method according to (AOAC 2000) and ash contents (AC) which measured by weight $100 \mathrm{~g}$ seed and set them in an oven at $80^{\circ} \mathrm{C}$ for three days and later at $750{ }^{\circ} \mathrm{C}$ for five hrs that turned it into ash.

\subsection{Genotypic Diversity Evaluation}

\subsection{DNA Extractionand SRAP - PCR Amplification}

Genomic DNA of the 15 barley cultivars under study were extracted from leaves using Cetyl Trimethyl Ammonium Bromide (CTAB) method according Doyle and Doyle (1990). PCR cycling was carried out as the following protocol; initial denaturation was done at $94{ }^{\circ} \mathrm{C}$ for $4 \mathrm{~min}$, followed by five cycles comprising for 1 -min denaturation at $94{ }^{\circ} \mathrm{C}, 1-\mathrm{min}$ annealing at $35^{\circ} \mathrm{C}$ and $30 \mathrm{~s}$ of elongation at $72{ }^{\circ} \mathrm{C}$. In the following 30 cycles, denaturation at $94{ }^{\circ} \mathrm{C}$ for $1 \mathrm{~min}$, annealing at $50{ }^{\circ} \mathrm{C}$ for $1 \mathrm{~min}$ and elongation at $72{ }^{\circ} \mathrm{C}$ for $30 \mathrm{~s}$ were carried out, ending with an elongation step for $10 \mathrm{~min}$ at $72{ }^{\circ} \mathrm{C}$. Ten Sequence Related Amplified Polymorphism (SRAP) primer combinations were used (their names and sequencing are listed in (Table 2).The PCR products were separated by agrose electrophoresis using 2\% gel in $1 \times$ TAE ( Tris-Acetate-EDTA) buffer against 100 bp DNA Ladder as a size marker. Bands were detected with ethidium bromide staining and visualized under UV light, then photographed for gel documentation.

Table 2: Ten SRAP primer combinations their names and sequencing

\begin{tabular}{lllll}
\hline No & Name & primer sequences & Name & primer sequences \\
\hline $\mathbf{1}$ & me1 & F: TGAGTCCAAACCGGATA & em1 & R: GACTGCGTACGAATTTGC \\
$\mathbf{2}$ & me1 & F: TGAGTCCAAACCGGATA & em3 & R: GACTGCGTACGAATTGAC \\
$\mathbf{3}$ & me2 & F: TGAGTCCAAACCGGAGC & em1 & R: GACTGCGTACGAATTAAT \\
$\mathbf{4}$ & me2 & F: TGAGTCCAAACCGGAGC & em3 & R:GACTGCGTACGAATTAAT \\
$\mathbf{5}$ & me2 & F:TGAGTCCAAACCGGAG & em4 & R:GACTGCGTACGAATTTGC \\
$\mathbf{6}$ & me4 & F:TGAGTCCAAACCGGAGC & em6 & R:GACTGCGTACGAATTGAC \\
$\mathbf{7}$ & me5 & F:GAGTCCAAACCGGAAG & em4 & R:GACTGCGTACGAATTTGC \\
$\mathbf{8}$ & me5 & F:GAGTCCAAACCGGAAG & em6 & R:GACTGCGTACGAATTGAC \\
$\mathbf{9}$ & me6 & F: TGA GTC CAA ACC GGA CA & em5 & R: GACTGCGTACGAATTTGC \\
$\mathbf{1 0}$ & me6 & F: TGA GTC CAA ACC GGA CA & em6 & R:GACTGCGTACGAATTGAC \\
\hline
\end{tabular}

\subsection{Data scoring and Statistical analysis}

\subsubsection{Phenotypic Studied Characters analysis}

Analysis of variance of all studied data traits of 15 barley cultivars were done according (Bartlett, 1937). All statistical analyses were performed using the computer software MSTAT-C Program according to (Steel et al., 1997). Simple correlation coefficients were computed among seed weight/plant and its components (Gomez and Gomez, 1984).

The principal components analysis was worked among traits for classifying the first two principal components that were graphically plotted against each other, using biplot graph according to Yan and Rajcan (2002). Hierarchical cluster and bi-plot analysis was performed using a computer software program Minitab v.19.

\subsubsection{Molecular markers analysis}

Amplified bands from SRAP primers were scored as a binary data under the heading of total scorable bands which determined for each cultivar, data were used to estimate the genetic similarity on the basis of number of shared amplification products (Nei and Li, 1979). Polymorphism information content (PIC) values were done to distinguish between cultivars for each primer according (Anderson et al., 1993). Un-weighted Pair-Group Method with Arithmetical (UPGMA) cluster analysis was performed to produce a denderogram on Jaccard's similarity coefficient using PAST program adapted by (Hammer et al., 2001). 


\section{Results}

\subsection{Phenotypic diversity among Egyptian barley cultivars}

The Bartlett's (1937) test results indicated homogeneous variance across seasons for all the phenotypic traits. Thus, a combined analysis of variance was conducted for all studied traits with homogeneous variance across the two seasons.

\subsection{Combined means performance of Physiological traits}

The results of combined analysis of variance (Table 3) indicated highly significant for physiological trails such as (flag leaf area $\left(\mathrm{cm}^{2}\right)$ and total chlorophyll (SPAD) with high differences genetic variation among all studied Egyptians barley cultivars.

Total Chlorophyll content (TCC) in this study considered as one of the major factors affecting photosynthesis. Results in Table (3) clearly indicated that the cultivars differed significantly in total chlorophyll content. Giza 2000 recorded the highest total chlorophyll content with value (48.2 SPAD reading) meanwhile, Giza 129 (38.7 SPAD reading) revealed the lowest content over all genotypes with an average (44.2 SPAD).

Flag leaf area is one of the important components in determining grain yield potential in cereal crop. Results in Table (3) obviously indicated that the cultivars diverged significantly in flag leaf area. Highest flag leaf area was found in naked barley Giza 131 with value of $9.5 \mathrm{~cm}^{2}$, however the lowest flag leaf area was found in Giza 127 with value of $5.4 \mathrm{~cm}^{2}$.

\subsection{Grain Yield and its Related Traits}

Analysis of variance of the four yield-related traits; number of grains spike ${ }^{-1}(\mathrm{NG} / \mathrm{S})$, number of tillers $\mathrm{m}^{-2}\left(\mathrm{NT} / \mathrm{m}^{2}\right)$, Thousand kernel weight $(\mathrm{TKW} / \mathrm{g})$ and grain yield $(\mathrm{GY})$ showed that all the Egyptian barley cultivars had highly significant genotypic differences for all yield traits as shown in Table (3). There were highly significant variation in thousand kernel weight (TKW) of barley cultivars based on their spike type and other genotypic traits. The highest (TKW) was found in Giza 127 (61.4 g) and Giza 128 (61.6 g) which they have two rows spike type. Means of (TKW) trait ranged from $46.1 \mathrm{~g}$ (Giza 132) to $61.6 \mathrm{~g}$ (Giza 128) among all cultivars with grand mean of $55.4 \mathrm{~g}$. Concerning the number of tillers $\mathrm{m}^{-2}\left(\mathrm{NT} / \mathrm{m}^{2}\right)$, the results in Table (3) showed that Giza 2000 gave the NT with values of (663.5 tillers $/ \mathrm{m}^{2}$, but Giza 135 and Giza 126 showed the lowest NT/m $/ \mathrm{m}^{-2}$ (340.0 and 364.2 tillers $/ \mathrm{m}^{2}$ ). Regarding the number of grains spike ${ }^{-1}(\mathrm{NG} / \mathrm{S})$, data in Table (3) showed that Giza 131 that had six row recorded the highest NG/S with value of (72.7 grains/spike) however, the lowest $\mathrm{NG} / \mathrm{S}$ value (28.3 grains/spike) was detected by Giza 127 with the two row.

Grain yield is a main and complex trait depending upon a large number of environmental, agronomical and physiological characters. In this study a significant differences was found among all cultivars with yield grand mean $16.7 \mathrm{ard} \mathrm{fed}^{-1}$. The highest grain yield value was determined by Giza 130 with 20.2 ard fed ${ }^{-1}$ followed by Giza $2000\left(19.6\right.$ ard fed $\left.^{-1}\right)$ and the lowest value are 15.1 ard fed $^{-1}$ in Giza 129 as showed in Table (3) and Fig (1).

\subsection{Barley Grain quality traits}

Barley grain is used primarily as energy, the main components of the barley grain were starch, protein and some minor components significantly affect the food-use quality of barley. In this investigation, the analysis of variance of grain quality traits such as Total starch content (TSC), grain protein content (GPC) and ash contents (AC) showed high different significant among all the Egyptian cultivars for all the studied traits as shown in Table (3) .

GPC was considered as a source for animal feed. High protein content is desirable for feed production. In this study, protein content ranged from $10.1 \%$ for Giza2000 to $15.2 \%$ for Giza135 (Table 3). The energy value of barley largely depends on its starch content, in this study high TSC found in Giza 127 was (49.6\%) and low starch content ratio was observed in Giza $123(40.7 \%)$ as showed in (Table 3), which all Egyptians barley cultivars display a large variation in starch content. Concerning the ash content, it represented the concentration of mineral contents in a food product, this study showed that ash percentage was found between low content of $2.0 \%$ in (Giza 123) to high percentage in Giza 126 with $2.5 \%$. 
Curr. Sci. Int., 10(1): 58-71, 2021

Table 3: Average value of physiological traits, quality traits, and yield, and its related traits of the 15 tested Egyptian barley cultivars over all two growing seasons

\begin{tabular}{|c|c|c|c|c|c|c|c|c|c|}
\hline \multirow[b]{2}{*}{ Cultivars } & \multicolumn{2}{|c|}{ Physiological traits } & \multicolumn{4}{|c|}{$\begin{array}{l}\text { Yield and its compounds } \\
\end{array}$} & \multicolumn{3}{|c|}{ Grain Quality traits } \\
\hline & $\begin{array}{c}\text { Total } \\
\text { Chlorophyll } \\
\text { SPAD } \\
\end{array}$ & $\begin{array}{c}\text { Flag leaf } \\
\text { area } \\
\left(\mathrm{cm}^{2}\right)\end{array}$ & $\begin{array}{c}\text { Thousand } \\
\text { kernel } \\
\text { weight (g) }\end{array}$ & $\begin{array}{c}\text { No. } \\
\text { tillers } \\
\text { m }^{2}\end{array}$ & $\begin{array}{l}\text { No. } \\
\text { grain } \\
\text { Spike }^{-1}\end{array}$ & $\begin{array}{c}\text { Grain } \\
\text { Yield } \\
\left(\text { ard fed }^{-1}\right)\end{array}$ & $\begin{array}{l}\text { Protein } \\
\text { content } \\
(\mathrm{g} / \mathbf{1 0 0 g})\end{array}$ & $\begin{array}{c}\text { Starch } \\
\text { content } \\
(\mathrm{g} / \mathbf{1 0 0 g})\end{array}$ & $\underset{\%}{\operatorname{Ash}}$ \\
\hline Giza 123 & 46.3 & 9 & 60.8 & 655.8 & 66.0 & 19.5 & 10.9 & 40.7 & 2.6 \\
\hline Giza 124 & 44.7 & 8.4 & 51.7 & 554.2 & 64.0 & 17.9 & 11.7 & 44.6 & 2.4 \\
\hline Giza125 & 47.7 & 8.7 & 54.3 & 365.8 & 62.0 & 15.7 & 10.8 & 44.0 & 2.4 \\
\hline Giza126 & 47.4 & 7.6 & 58.3 & 364.2 & 72.0 & 16.7 & 10.6 & 45.3 & 2.5 \\
\hline Giza127 & 41.6 & 5.4 & 61.4 & 619.2 & 28.3 & 17.7 & 10.7 & 49.6 & 2.2 \\
\hline Giza128 & 44.2 & 6.2 & 61.6 & 613.8 & 29.0 & 18.8 & 11.1 & 46.9 & 2.3 \\
\hline Giza 129 & 38.7 & 6.3 & 56.4 & 466.7 & 66.0 & 15.1 & 11.8 & 46.3 & 2.2 \\
\hline Giza 130 & 46.3 & 7.1 & 52.9 & 643.8 & 63.0 & 20.2 & 11.9 & 47.6 & 2.2 \\
\hline Giza 131 & 48.6 & 9.5 & 60.2 & 549.2 & 72.7 & 17.7 & 12.1 & 40.3 & 2.0 \\
\hline Giza 132 & 41.3 & 7.9 & 46.1 & 468.3 & 61.0 & 14.6 & 11.1 & 41.9 & 2.2 \\
\hline Giza 133 & 44.6 & 7.9 & 54.6 & 603.3 & 64.0 & 15.4 & 11.4 & 41.1 & 2.3 \\
\hline Giza 134 & 45.5 & 5.8 & 55.1 & 557.5 & 66.0 & 15.2 & 10.2 & 40.4 & 2.4 \\
\hline Giza 135 & 44.9 & 7.9 & 51.9 & 340.0 & 66.7 & 16.5 & 15.2 & 41.9 & 2.3 \\
\hline Giza 136 & 48.1 & 8.7 & 48.7 & 486.7 & 72.1 & 18.2 & 12.2 & 40.4 & 2.1 \\
\hline Giza 2000 & 48.2 & 8.9 & 56.3 & 663.5 & 71.3 & 19.6 & 10.1 & 43.5 & 2.4 \\
\hline Grand mean & 44.2 & 7.7 & 55.4 & 517.1 & 62.1 & 16.7 & 11 & 42.8 & 2.3 \\
\hline LSD 0.05 & 1.6 & 1.9 & 1.6 & 24.9 & 2.0 & 0.5 & 0.4 & 1.5 & 2.3 \\
\hline \multicolumn{10}{|c|}{ Analysis of variance ( F Test) } \\
\hline Cultivars C & $* *$ & $* *$ & $* *$ & $* *$ & $* *$ & $* *$ & $* *$ & $* *$ & $* *$ \\
\hline
\end{tabular}

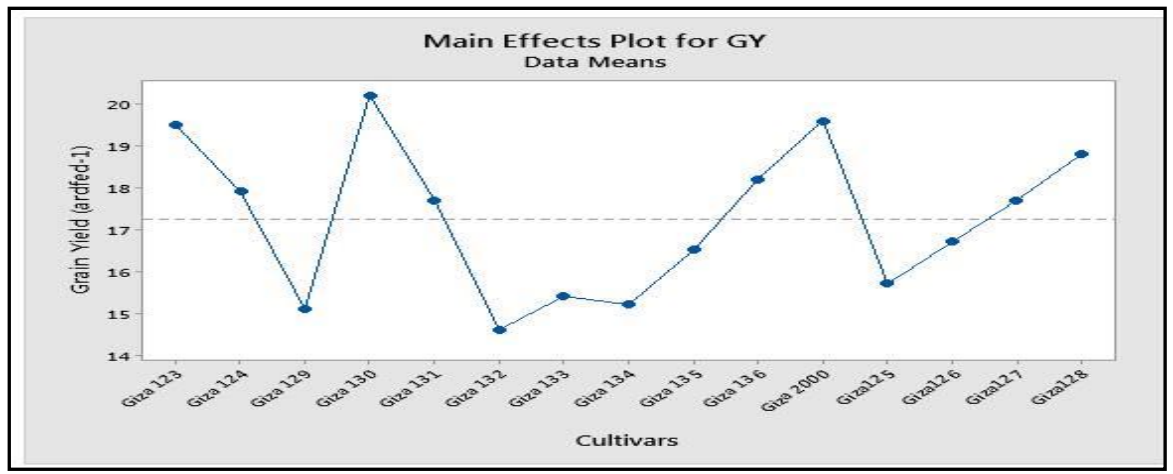

Fig. 1: The main effects plot for grain yield among the 15 Egyptians barley cultivars.

\subsection{Relationships among Phenotypic Studied Traits}

To understand the relationships among analysis phenotypic studied traits simple correlation coefficient and the principal component analysis (PCA) analysis was applied. In this study, simple correlation coefficients among all studied traits are shown in (Table 4).

Table 4: Correlation coefficients among the studied traits across two seasons

\begin{tabular}{lllllllll}
\hline & TCC & FLA & TKW & NT & NG & GPC & TSC & ASH \\
\hline FLA & $0.644^{* *}$ & & & & & & & \\
TKW & 0.063 & -0.232 & & & & & & \\
NT & 0.019 & -0.110 & 0.374 & & & & & \\
NG & 0.450 & $0.651^{* *}$ & -0.420 & -0.308 & & & & \\
GPC & -0.055 & 0.171 & -0.321 & -0.430 & 0.182 & & & \\
TSC & -0.417 & $-0.604^{*}$ & 0.331 & 0.136 & $-0.653^{* *}$ & -0.171 & & \\
ASH & 0.296 & 0.185 & 0.271 & -0.006 & 0.098 & -0.356 & -0.179 & \\
GY & 0.461 & 0.224 & 0.339 & $0.604^{*}$ & -0.124 & -0.042 & 0.244 & 0.071 \\
\hline
\end{tabular}

$*$ and ${ }^{* *}$ : Significant at p-value $=0.05$ and 0.01 . TCC: total chlorophyll content, FLA: flag leaf area, TKW: Thousand kernel weight, NG/S: number of grains/spike, NT: number of tillers $\mathrm{m}^{2}$, GPC: grain protein content, TSC: total starch content, ASH: ash content and GY: grain yield. 
Results revealed significant positive correlation coefficient among total chlorophyll content (TCC), flag leaf area (FLA), grain yield (GY), and number of grains/spike (NG/S). Whereas, negative significant correlation was obtained among total starch content (TSC), flag leaf area (FLA) and number of grains/spike (NG/S). Moreover, non-significant correlation found between almost studied traits.

The loadings of PC1 presented in the horizontal axis indicated the direction of association among the studied traits. The first and two principal components accounted for $57.6 \%$ (PCA1 $=30.7 \%$ + PCA2 $=26.9 \%$ ) of the total variability (Fig. 2$)$. So, it is noted that the three traits of $(\mathrm{NG} / \mathrm{S})$ number of grains/spike, (FLA) flag leaf area and (GPC) grain protein content located in the left side (negative) of the horizontal axis according to their negative correlations with most other traits (Table 4 and Fig 2 ). Therefore, (TSC) total starch content recorded negative and significant correlation $\left(-0.653^{* *}\right.$ and 0.604*) with (NG/S) and (FLA), respectively. The PCA2 loadings divided the studied traits into similar classes. Accordingly, the traits with the nearest vector length that located in the one quarter of the graph are more correlated. Therefore, $(\mathrm{NG} / \mathrm{S})$ number of grains/spike was the nearest neighbor and with nearest vector length (more correlated) to (FLA) flag leaf area with that located in the same quarter (positive correlated) recording $\left(0.651^{* *}\right)$. Accordingly, (GY) grain yield correlated with $\left(\mathrm{NT} / \mathrm{m}^{2}\right)$ number of tillers $\mathrm{m}^{2}$ and (TCC) total chlorophyll content with (FLA) flag leaf area recording $\left(0.604 *\right.$ and $\left.0.644^{* *}\right)$, respectively. These results confirmed the correlation results for the importance of number of grains spike ${ }^{-1}$, flag leaf area, total chlorophyll content and number of tillers $\mathrm{m}^{2}$ as selection criteria for yield development in barley.

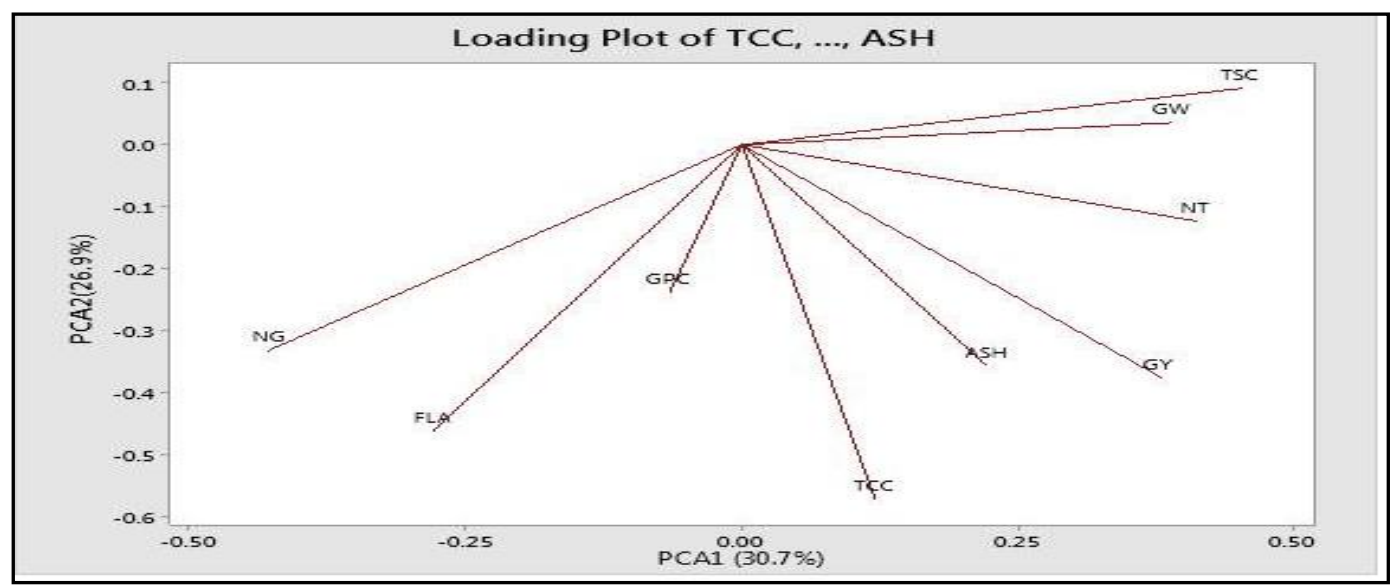

TC: total chlorophyll content, FLA: flag leaf area, TKW: Thousand kernel weight, NG/S: number of grains/spike, NT: number of tillers m2, GPC: grain protein content, TSC: total starch content, ASH: ash content and GY: grain yield

Fig 2: Loading plot graph, showing the first two principal components (PCA) of the correlation matrix among the studied traits.

\subsection{Phenotypic diversity among Egyptian Barley cultivars}

Bi-plot analysis and Hierarchical Cluster analysis were used to classificate the cultivars based on principal component analysis and the average of all the phenotypic studied characters. In this study, bi-plot analysis classified all the15 cultivars into four classes as shown in (Fig 3). Also the hierarchical cluster analysis was construct a distance matrix using the Euclidian coefficient average linkage method are graphically illustrated in dendrogram showing similarity among all the cultivars (Fig 4). The 15 cultivars had divided into five groups. The first group include four Egyptian barley cultivars (Giza123, 126, 127, 131 and 2000) which they had the highest GY and high performance of almost studied traits. The second group include four barley cultivars (Giza 124, 134, 132 and 131). The third group include two cultivars (Giza 129 and Giza 135), forth group had low GY and moderated performance for almost traits and including two barley cultivars (Giza 127 and Giza 128) and the fifth group, consist of three barley cultivars (Giza 125, 126 and 135). 


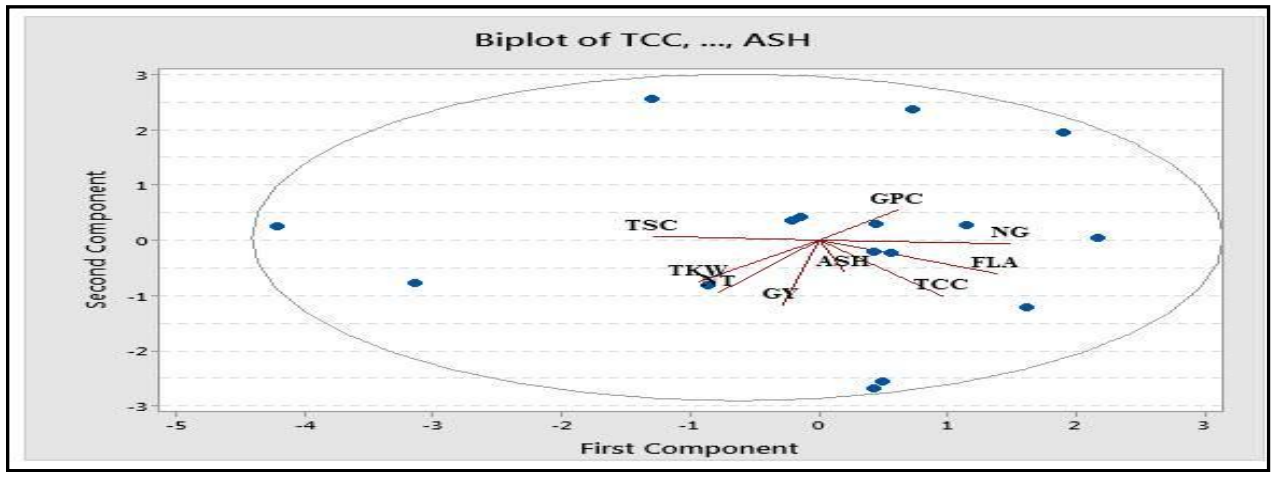

Fig. 3: Bi-plot alaysis of sutied trais to classify 15 barley cultivars.

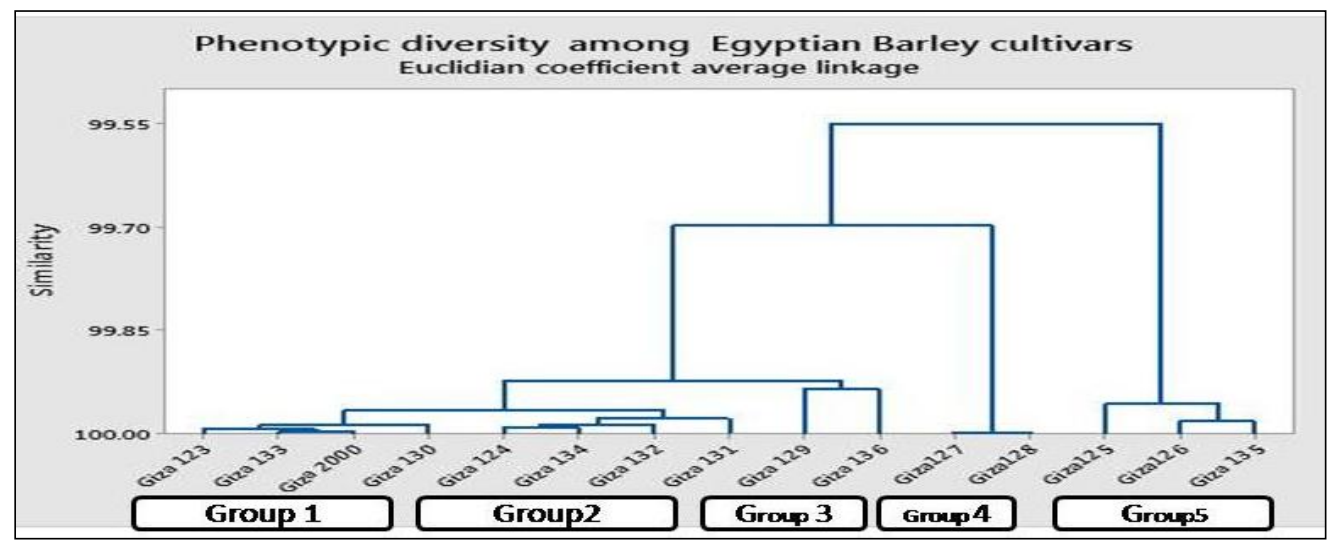

Fig. 4: Cluster analysis based on phenotypic traits to classify 15 barley cultivars.

\subsection{Molecular diversity analysis among the Egyptians barley cultivars}

\subsubsection{Amplification results of SRAP-PCR marker analysis}

Results in Table (5) showed that the total fragments were 90, in which 65 fragments were polymorphic, however 25 fragments were monomorphic. The number of amplified bands for each pair of primers was ranged from six bands in (me1+em1) to thirteen bands in (me5+ em6) (Fig 5) with an average of $6.5 \%$ per primer combination.

Table 5: List of used SRAP primers: names, number of total fragment, number of polymorphic bands, polymorphism \% and polymorphism information contents (PIC)

\begin{tabular}{llcccc}
\hline & Name & $\begin{array}{c}\text { No. of Total } \\
\text { band }\end{array}$ & $\begin{array}{c}\text { No. of polymorphic } \\
\text { Bands }\end{array}$ & $\begin{array}{c}\text { Polymorphism } \\
\text { \% }\end{array}$ & $\begin{array}{c}\text { polymorphic information } \\
\text { content (PIC) }\end{array}$ \\
\hline $\mathbf{1}$ & me1 $+\mathrm{em} 1$ & 6 & 1 & 16.6 & 0.18 \\
$\mathbf{2}$ & me2+em3 & 9 & 7 & 77.7 & 0.78 \\
$\mathbf{3}$ & me6+em3 & 10 & 8 & 80.0 & 0.89 \\
$\mathbf{4}$ & me5+em5 & 10 & 9 & 90.0 & 0.92 \\
$\mathbf{5}$ & me2+em4 & 8 & 6 & 75.0 & 0.76 \\
$\mathbf{6}$ & me4+em6 & 7 & 4 & 57.1 & 0.58 \\
$\mathbf{7}$ & me5+em4 & 7 & 2 & 28.5 & 0.20 \\
$\mathbf{8}$ & me5+em6 & 13 & 11 & 84.6 & 0.89 \\
$\mathbf{9}$ & me6+em5 & 10 & 8 & 80.0 & 0.82 \\
$\mathbf{1 0}$ me6+em6 & 10 & 9 & 90.0 & 0.94 \\
$\begin{array}{l}\text { Average } \\
\text { Total }\end{array}$ & 9.0 & 6.5 & 67.95 & 0.68 \\
\hline
\end{tabular}




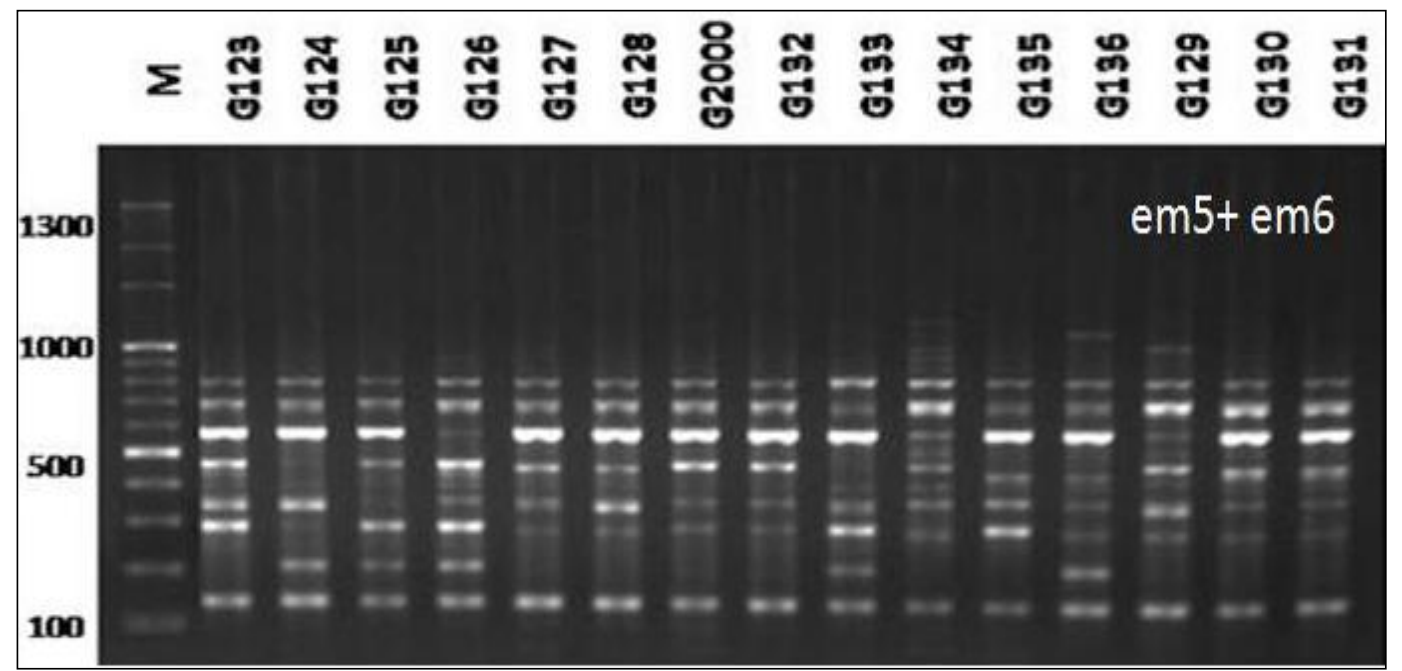

Fig. 5: Agarose gel electrophoresis of SRAP amplification products of different 15 Egyptian barley cultivars.

The average percentage of polymorphic loci for all primer combinations was $67.95 \%$ and the average band number amplified from each pair of primers was $9.0 \%$ bands, of which included $6.5 \%$ polymorphic bands. Highest polymorphism (90\%) was found by primer (me5+em5 and primer me6+em6). Lowest polymorphism (16.6\%) was found by primer me1+ em1. Polymorphic information content (PIC) values, was used to measure the genetic diversity for ten SRAP primes were ranged from lowest PIC value $(0.18 \%)$ related to primer combination me1+em1 to highest PIC value $(0.94 \%)$, which was related to primer combination me $6+$ em6 with an average $0.67 .95 \%$. Indicating that this primer combination me $6+$ em 6 was highly informative and could be useful primer set to confirm the genetic differences among the studied barley cultivars.

\subsubsection{Genetic diversity among the 15 cultivars using SRAP markers}

Genetic diversity indices include percentage of polymorphic bands, Simpson index (SI), Shannon's information index (SII) and Berger- Parker index(BPI) were important indices to estimate the levels of genetic diversity among the 15 Egyptian barley cultivars using ten SRAP primers were shown in Table (6). Percentage of polymorphic loci ranged from 70.4\% (Giza 124) to 80.5\% for Giza 136). The obtained Simpson index ranged from 0.9800 for Giza 124 to 0.9825 for Giza 136 with an average (0.9805). About Shannon's information index ranged from 3.9120 (Giza 124) to 4.0435 (Giza 136) with average (3.3988). About Berger-Parker index the values ranged from 0.0177 (Giza 136) to 0.0200 (Giza 124).Furthermore, the changes of these indices were dependable on the percentage of polymorphic loci.

\subsubsection{UPGMA Cluster analysis}

Cluster analysis shaped a dendrogam among the 15 Egyptian barley cultivars based on ten SRAP fragments using Jaccard's genetic similarity coefficient was outlined by UPGMA method as shown (Fig 6). The dendrogram of SRAP markers had clustered all the Egyptian cultivars into six groups (Fig.6) each group include the most closest cultivars together. Group I consisted of four Egyptian barley cultivars (Giza 123, 2000, 131 and 133), group II include two Egyptian barley cultivar (Giza 130 and Giza 128), group III consisted of two Egyptian barley cultivar Giza 127 and Giza 135), group VI consisted of two Egyptian barley cultivar Giza 124 and Giza 134), group V consisted of two Egyptian barley cultivar Giza 129and 132) and group IV its included three cultivars were (Giza 126, Giza 125 and Giza 136), Indicting the close relationship within each of this pair of barley cultivars. 
Curr. Sci. Int., 10(1): 58-71, 2021

Table 6: Genetic diversity indices SI,SII and BPI among 15 barley cultivars using ten SRAP primer combinations.

\begin{tabular}{lccccc}
\hline Cultivars & $\begin{array}{c}\text { Total } \\
\text { polymorphic } \\
\text { band }\end{array}$ & $\begin{array}{c}\text { Percentage of } \\
\text { Polymorphic bands }\end{array}$ & $\begin{array}{c}\text { Simpson } \\
\text { Index (SI) }\end{array}$ & $\begin{array}{c}\text { Shannon's } \\
\text { information } \\
\text { index (SII) }\end{array}$ & $\begin{array}{c}\text { Berger-Parker } \\
\text { Index (BPI) }\end{array}$ \\
\hline G123 & 51 & 71.8 & 0.9804 & 3.9320 & 0.0196 \\
G124 & 50 & 70.4 & 0.9800 & 3.9120 & 0.0200 \\
G125 & 57 & 80.2 & 0.9824 & 4.0430 & 0.0175 \\
G126 & 56 & 78.8 & 0.9821 & 4.0250 & 0.0179 \\
G127 & 55 & 77.4 & 0.9818 & 4.0070 & 0.0182 \\
G128 & 53 & 73.2 & 0.9811 & 3.9700 & 0.0189 \\
G2000 & 47 & 66.2 & 0.9787 & 3.8500 & 0.0213 \\
G132 & 51 & 71.8 & 0.9804 & 3.9320 & 0.0196 \\
G133 & 54 & 76.1 & 0.9815 & 3.9890 & 0.0185 \\
G134 & 51 & 71.8 & 0.9804 & 3.9320 & 0.0196 \\
G135 & 51 & 71.8 & 0.9804 & 3.9320 & 0.0196 \\
G136 & 57 & 80.3 & 0.9825 & 4.0433 & 0.0175 \\
G129 & 55 & 77.5 & 0.9818 & 4.0072 & 0.0182 \\
G130 & 54 & 76.1 & 0.9815 & 3.9890 & 0.0185 \\
G131 & 53 & 74.7 & 0.9811 & 3.9700 & 0.0189 \\
Average & 51.53 & 72.5 & 0.9805 & 3.9386 & 0.0195 \\
\hline
\end{tabular}

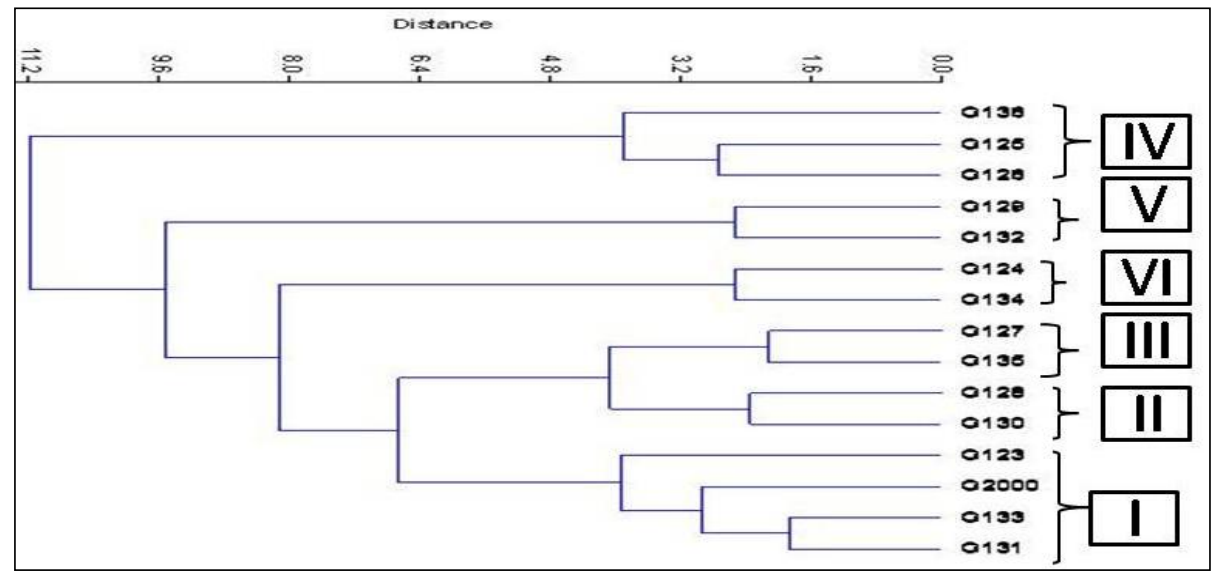

Fig. 6: Dendrogram obtained from UPGMA cluster based on SRAP data

\subsection{Combined analysis of phenotypic and genotypic data}

Genetic diversity assessment using the combined phenotypic and molecular information among the 15 Egyptian barley cultivars were identified to be clustered into the same position across the two hierarchical cluster and UPGMA cluster analysis (Fig.7) using Neighbor Joining (NG) method was outlined by the UPGMA cluster analysis, the diagram divided the 15 cultivars into five groups as shown in Fig (7). Group I involved three cultivars (Giza 126, 135 and 125), group II include three cultivar (Giza 129, 132 and Giza 136), group III consisted of two Egyptian barley cultivar (Giza 124 and Giza 131), group VI consisted of six Egyptian barley cultivar (Giza 123,2000, 130, 127,128 and Giza 133), group V include one cultivar (Giza 134). In this study, the observed grouping patterns and membership had a small difference between the cluster from phenotypic and the cluster from molecular information. 


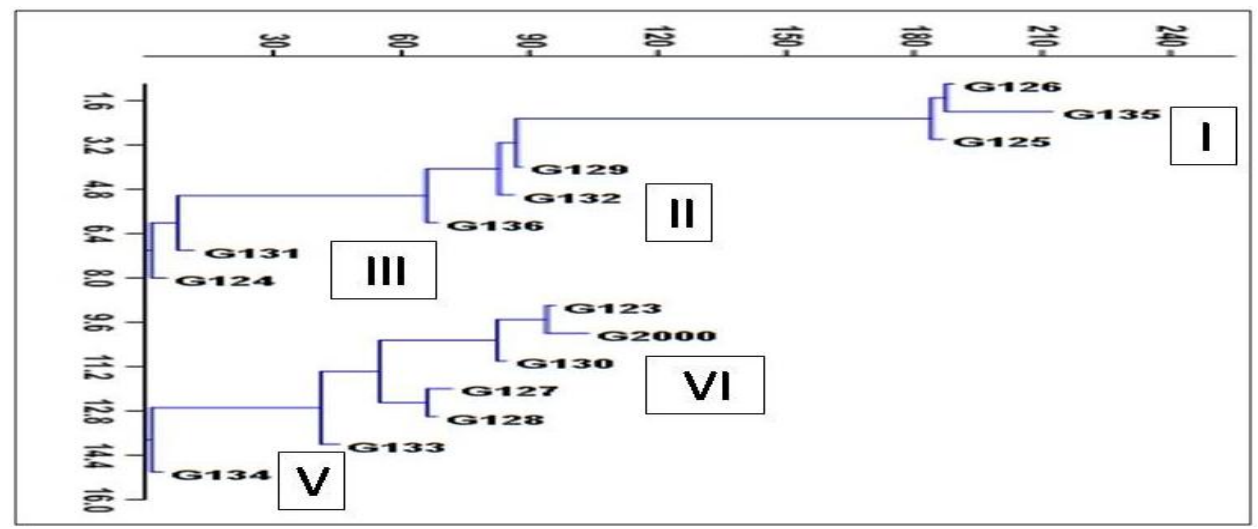

Fig. 7: The similarity dendrogram of combined analysis of phenotypic and genotypic data of 15 barley cultivars produced by ten SRAP primers using Neighbor Joining (NG) method

\section{Discussion}

\subsection{Diversity and differentiation based on phenotypic traits.}

Existence of significant differences in phenotypic traits was evaluated by analysis of variance. In this study, the analysis of variance indicated high the significant difference for all the phenotypic traits such as physiological, grain yield and related traits and grain quality traits with the high differences genetic variation among all the 15 Egyptians barley cultivars. This results are indicator that the 15 Egyptian barley have the great potential to utilize in breeding programs for different environment stresses. Our results were in agreements with (Mariey et al., 2017a; Naser et al., 2018 and Alghabari and Ihsan, 2018) which they established a high significant for the Agro-physiological traits and grain quality traits in barley. Our results indicated high performance for Egyptian cultivars (Giza 2000, Giza 123, Giza 130, Giza131 and Giza 133 in almost of studied traits. This results in a good harmony with (Mariey et al., 2017a)

Information about the relationship between different traits in breeding programs to get better yield are essential, which could using in finding out the genetic variability accessible and utilization in breeding programs (Ibrahim et al., 2011 and Jouyban et al., 2015).In our study,positive significant correlation between grain yield and TCC, FLA, TKW/g, NT/m2, NG/S were observed, It could be concluded that indirect selection based on that traits which had positive and significant correlation with grain yield can be used to increase grain yield. Our results were in agreement with Mariey et al,. 2017a ;Naser et al., 2018; Mariey et al., 2020 and Verma et al., 2020) which They confirmed that Grain yield is an final product of the action and interaction of a large number of environmental, agronomical and physiological characters. Also, reported that the selections for high yielding genotypes under optimum conditions allow genotypes to maintain their high ranks in stress environment, because it is expected that the samegenotypes will perform high under stressed environments.

Hierarchical Cluster Bi-plot analysis based on phenotypic traits were aimed to detect homogeneous groups with large heterogeneity among them, also considered as a valuable tool for subdividing number of genotypes in groups including similarity and dissimilarity genotypes in order to help the breeder to plan an effective breeding program (Saroei et al., 2017). As a result, the cluster analysis assigned the 15 cultivars based on agro- physiological traits, and grain quality into four clusters.These results were in agreement with previous studies Meng et al., 2016; Mariey and Khder, 2017; Saroei et al., 2017; Arshadi, 2018; Mariey et al., 2018a; Mahalingam, 2019 and Dawood et al., 2020). The hierarchical cluster and bi-plot analysis based on agro- physiological traits and grain quality to subdivided barley genotypes in different groups to used get a new lines from crossing them, which could use them in breeding programmers for environment stresses.

\subsection{Diversity and differentiation based on molecular markers}

Assessment of genetic diversity using molecular markers is one of the primary and important steps in breeding programs. SRAP marker is a powerful technique for the assessment of genetic variability because it has shown a high degree of reproducibility and discriminatory power, as well as 
a high polymorphism rate in many genetic studies (Ahmed et al., 2017). In this study, genetic diversity of 15 barley cultivars was evaluated by ten SRAP primer combinations which gave 88 alleles. Theses alleles number were higher than other alleles which protected by other DNA marker. Different polymorphism and number of amplified band has been detected in barley using SRAP markers (Fufa et al., 2005). High polymorphic rate (100\%) and PIC value (0.96) together with the moderated genetic similarity (0.96) was observed among 15 cultivars in this study, suggests a high level of heterogeneity will be found in the Egyptian barley cultivars, high polymorphism alleles. Our results agree with those obtained (Said et al., 2015, Mariey et al., 2017b and 2018 b) which they used SRAP marker to evaluated the genetic diversity in barley and they suggested that SRAP technology is useful for genetic diversity and relationship analyses, marker assisted selection and genetic map construction in barley.

\subsection{Combined analysis of phenotypic and genotypic data}

The knowledge of genetic diversity available with phenotypic evaluations one of important factors to understand and investigate in germplasm collections or breeding material helps the breeders to plan their programs for specific environments using targeted traits and molecular markers (AlAbdallat et al., 2017). There were many investigations studied the genetic diversity in barley coupled phenotypic traits with different DNA markers, such as, Morph-physiological traits with SRAP (Mariey et al., 2017b and 2018b ) ISSR ( Mariey et al., 2018a and Ahmed et at., 2020), SSR ( Mariey et al., 2016, Sallam et al., 2018 and Mariey et al.,2020), SNP (Verma et al., 2020). A few studied using both agro-physiological and grain quality with DNA markers were done. In the present study, agro-Physiological traits and grain quality were used with molecular analyses SRAP markers to investigate the genetic relationships among the 15 Egyptian barley cultivars and we confirmed that the combined information on the changes in grain yield and important agro-physiological traits were useful in assessment the genetic diversity among barley cultivars. Our study in a good harmony with (Sallam et al., 2018 and Dawood et al., 2020) whom study the genetic diversity in barley genotypes using agro-physiological traits and grain quality with DNA marker.

\section{Conclusion}

Combined information about both agro-Physiological traits and grain quality with SRAP markers were constructive apparatus in investigating genetic relationships among barley cultivars. In this work the dendrogram cluster based on SRAP rather than agree with the dendrogram cluster based Agro-Physiological traits and grain quality characters distance. Also, the range of genetic distance based on phenotypic characters was on average near to SRAP markers. From these results it is noted that 15 Egyptian barley cultivars showed a high significant variation in agro-physiological traits and grain quality and SRAP polymorphisms. The SRAP data can be used in selecting diverse parents in breeding program and in maintaining genetic variation in the germplasm. Furthermore the results provide new information about the relationships between Egyptian barley cultivars which they are useful for cultivar identification and for their utilization in further barley breeding program in Egypt for environmental stress.

\section{References}

Abu El-lail, F.F.B., K.A. Hamam, K.A. Kheiralla and M.Z. El- Hifny, 2014. Salinity tolerance in 280 genotypes of two rows barley. Egyptian Journal of Plant Breeding. 18: 331-345.

Ahmad, F., A. Akram, K. Farman, T. Abbas, A. Bibi, S. Khalid and M. Waseem, 2017. Molecular markers and marker assisted plant breeding: current status and their applications in agricultural development. J. Environ. Agric. Sci., 11: 35-50.

Al-Abdallat, A.M., A. Karadsheh, N. Hadadd, S.M.A. Ceccarelli, M. Baum, M. Hasan, A. Jighly, and M. Abu Elenein, 2017. Assessment of genetic diversity and yield performance in Jordanian barley (Hordeum vulgare L.) landraces grown under Rainfed conditions. BMC Plant Biology. $17: 191$.

Alghabari, F. and Z. Ihsan, 2018. Effects of drought stress on growth, grain filling duration, yield and quality attributes of barley (Hordeum vulgare). Bangladesh J. Bot. 47: 421-428. 
Anderson, J.A., G.A. Churchill, J.E. Autrique, S.D. Tanksley, and M.E. Sorrels, 1993. Optimizing parental selection for genetic linkage maps. Genome. 36:181-186.

AOAC, 2000. Official method of analysis ( $17^{\text {th }}$ ed.). Gaithersburg, MD, USA: Association of Official Analytical Chemists, 21:967.

Arshadi, E., A. Karami, M. Sartip and P. Rezabakhsh, 2018. Genotypes performance in relation to drought tolerance in barley using multi-environment trials. Agronomy Research 16.

Bartlett, M.S., 1937. Properties of sufficiency and statistical tests. Proceedings of the Royal Statistical Society Series, 160: 268.

Botstein, D., R.L. White, M. Skolnick, and R.W. Davis, 1980. Construction of a genetic linkage map in man using restriction fragment length polymorphisms. Am. J. Hum. Genet. 32: 314-331.

Dawood, M.F.A., Y.S. Moursi, A. Amro, S. Baenziger, and A. Sallam, 2020. Investigation of HeatInduced Changes in the Grain Yield and Grains Metabolites, with Molecular Insights on the Candidate Genes in Barley. Agronomy. 10: 1730.

Dora, S.A., M. Mansour, A.A. Aboulila and E. Abdelwahab, 2017. Genetic Diversity and Relationships among Some Barley Genotypes for Net Blotch Disease Resistance Using RAPD, SCoT and SSR Markers. Egyptian Journal of Genetics and Cytology 46: 139-165

Doyle, J.J. and J.L. Doyle., 1990. A rapid DNA isolation procedure for small quantities of fresh leaf tissue. Focus.12: 13-15.

Dubois, M., K.A. Giles, J.K. Hamilton, P.A. Robbers and F. Smith, 1956. Colorimetric method for determination of sugars and related substances. Anal. Chem. 28: 350-356.

FAO STAT, 2017. Crops/Regions/World List/Production Quantity for Barley. Available at https://www.fao.org/faostat/en/\#data/QC (accessed on August 2019).

Fufa, H., P.S. Baenziger, B.S. Beecher, I. Dweikat, R.A. Graybosch and K.M. Eskridge, 2005. Comparison of phenotypic and molecular marker-based classifications of hard red winter wheat cultivars. Euphytica. 145: 133-146.

Gomez, K.A. and A.A. Gomez, 1984. Statistical procedures For Agricultural Research. 2nd Ed. John Wiley \& Sons, Inc.

Guasmi, F., W. Elfalleh, H. Hannachi, K. F'eres, L. Touil, N. Marzougui, T. Triki, and A. Ferchichi, 2012. The use of ISSR and RAPD markers for genetic diversity among south Tunisian barley. Agronomy, 1:10

Hammami, Z., H. Sbei, K. Kadri, Z. Jmel, A. Sahli, M. Fraj, H. Naser, A. Jaime, H. Silva, and Y. Trifa, 2016. Evaluation of performance of different barley genotypes irrigated with saline water in South Tunisian Saharan conditions. Environmental and Experimental Biology, 14: 15-21.

Hammami, Z., N. Ahmed, N. Hmida, S. Tounsi, S. Ayadi, and Y. Trifa, 2020. The Arsenal of Morphological and Physiological Mechanisms Adopted by Barley (Hordeum vulgare L) to Face Salt Stress Damage". Acta Scientific Agriculture, 4:92-101.

Hammer, Ø.D., A.T. Harper and P.D. Ryan, 2001. Paleontological statistics software package for education and data analysis, Palaeontologia Electronica. 4: 1-9.

Ibrahim, O.M., Mohamed Magda H., M.M. Tawfik, and Badr A. Elham, 2011. Genetic diversity assessment of barley (Hordeum vulgare L.) genotypes using cluster analysis. International journal of academic research. 3: 2 .

Ismail, N.A., M.Y. Rafii T.M.M., Mahmud, M.M. Hanafi and G. Miah, 2016. Molecular markers: a potential resource for ginger genetic diversity studies. Mol. Biol. Rep. 43: 1347-1358

Jouyban, A., H. Sadeghi Give, and M. Noryan, 2015. Relationship between agronomic and morphological traits in barley varieties under drought stress condition. Intl. Res. J. Appl. Basic. Sci., 9: 1507-1511.

Li, G. and C.F., Quiros, 2001. Sequence-related amplified polymorphism (SRAP) a new marker system based on a simple PCR reaction, its application to mapping and gene tagging in Brassica. Theor. Appl. Genet. 103:455-461.

Mahalingam, R. and P. Bregitzer, 2019. Impact on physiology and malting quality of barley exposed to heat, drought and their combination during different growth stages under controlled environment. Physiol Plant, 165:277-289

Mariey, A. Samah Mona A. Farid and I. A. Khatab (2016). Physiological and Molecular characterization of some Egyptian barley (Hordeum vulgare 1.) cultivars for salt tolerance. Egypt. J. Genet. Cytol., 45:367-382 
Mariey, A. Samah and Khedr A. Rania, 2017. Evaluation of some Egyptian barley cultivars under water stress conditions using drought tolerance indices and multivariate analysis. J. Sus. Agric.Sci. 43: 105

Mariey, A. Samah, Rania, A. Khedr, Zayed, B.A., and Ammar. A. Elakhdar, 2017a. Genetic Variability among Egyptian Barley varieties for agro- morphological traits under saline soil condition .Egypt. J. Plant Breed 21:577-593

Mariey, A. Samah, M.A. Aiad and I.A. Khatab, 2017b. Genetic diversity and phenotypic association with salinity tolerance in Egyptian barley cultivars using SRAP markers. Journal of Environmental and Agricultural Sciences. 13: 51-66.

Mareiy, A Samah, Mona A. Farid and A. R. Karima, 2018a. Morphological and Molecular Characterization of Some Egyptian Barley Cultivars under Calcareous Soil conditions. Middle East Journal of Agriculture 7:408-420

Mareiy, A Samah, Mona A.M. El-Mansoury and Maha A El-Bialy, 2018b. Genetic Diversity Study of Egyptian Barley Cultivars Using Sequence-Related Amplified Polymorphism (SRAP) Analysis for Water Stress Tolerance .J. Sus. Agric .Sci., 44: 21 - 37

Mariey, Samah A., Amany M. Mohamed and Heba G. Ali, 2018c. Effect of salinity stress on physiological and biochemical traits of barley cultivars. International Journal of Environment 7: 65-77

Mariey, A. Samah, Mona A.M. El-Mansoury and and Amin M.E Agwa, 2020. Genetic Diversity of Egyptian barley cultivars for Water Stress using SSR markers. International Journal of Environment 9: 14-24

Meng, Y., P. Ren, X. Ma, B. Li, Q. Bao, H. Zhang, J. Wang, J. Bai, and H. Wang, 2016. GGE BiplotBased Evaluation of Yield Performance of Barley Genotypes across Different Environments in China. Journal of Agricultural Science and Technology 18: 533.

Monireh, R., M. Islam, V. Mostafa, D.K. Farokh and E. Farshad, 2014. Genetic Diversity among Wild and cultivated barley by ISSR Marker. Bull. Env. Pharmacol. Life Sci. 3:10: 57-62

Naser, M., M. Badran, H. Abouzied, Ali Heba and I. Elbasyoni, 2018. Phenotypic and Physiological Evaluation of Two and Six Rows Barley under Different Environmental Conditions . Plants, 7:39.

Nei, M. and W.H. Li, 1979. Mathematical model for studying genetic variation in terms of restriction endonucleases. Proc. Natl. Acad. Sci., 76:5269-5273.

Noli, E., S. Salvi and R. Tuberosa, 1997. Comparative analysis of genetic relationships in barley based on RFLP and RAPD markers. Genome 40: 607-616.

Said, A.A., A. Hamada, M. Youssef, N.E. Mohamed and A.A. Mustafa, 2015. SRAP Markers Associated with Water Use Efficiency and Some Agronomic Traits in Wheat under Different Irrigation Regimes. Egypt. J. Agron. 37: 209 - 229

Salem, K.F.M., R.K. Varshney, M.S. Röder and A. Börner, 2010. EST-SSR based estimates on functional genetic variation in a barley (Hordeum vulgare L.) collection from Egypt. Genet Resource Crop Evol. 57 (4): 515-521

Sallam, A., A. Amro, A. EL-Akhdar, M.F.A. Dawood, T. Kumamaru and P. Baenziger, 2018. Genetic diversity and genetic variation in morpho-physiological traits to improve heat tolerance in spring barley. Mol Biol Rep., 45:2441-2453.

Saroei, E., K. Cheghamirza and L. Zarei, 2017. Genetic diversity of characteristics in barley cultivars.- Genetika, 49(2): 495-510.

Sharma, P., S. Sareen, M. Saini and A. Shefali, 2017. Assessing genetic variation for heat stress tolerance in Indian bread wheat genotypes using morpho-physiological traits and molecular markers. Plant Genet Resour, 15:539-547.

Steel, R.G.D., J.H. Torrie, and D.T. Deekey, 1997. Principles and procedures of statistics: “A Biometrical Approach" 3rd ed., McGraw Hill Book Co., Inc. New York

Varshney, R., K.F.M. Salem, M. Baum, M.S. Röder, A. Graner and A. Börner, 2008. SSR and SNP diversity in a barley germplasm collection. Plant Genet. Res. 6: 167

Verma, S., Y. Shikha, R. Sajid, G. Sanjaya, K. Yogender, C. Shiaoman, S. Ashutosh, P. Ramesh, and S. Verma, 2020. Genetic and Agro-morphological diversity in global barley (Hordeum vulgare L.) collection at ICARDA. Genet Resour Crop Evol. 
Yan, W. and I. Rajcan, 2002. Biplot analysis of test sites and trait relations of soybean in Ontario. Crop Sci., 42: 11-20.

Yang, P., X. Liu, X. Liu, W. Yang, and Z. Feng, 2010. Diversity analysis of the developed qingke (hull-less barley) cultivars representing different growing regions of the Qinghai-Tibet Plateau in China using sequence related amplified polymorphism (SRAP) markers. African Journal of Biotechnology. 9:8530-8538. 